\title{
Female Suffrage
}

\begin{abstract}
Even if the history of female suffrage in Switzerland is well documented in many respects, its relation to migration has never been systematically analysed. This chapter shows how some of the most prominent figures in the struggle for female suffrage were connected to experiences of migration. It also discusses the example of a woman who lost her citizenship because she married a 'foreigner' and shows why it is heuristically productive, when studying migration, to take such experiences into account. In addition, the connections between women's right to vote in cultural memory and its interrelation to migration are brought to the fore. In this context, the chapter points out that it could be a productive undertaking to systematically investigate how, in Switzerland, women with an experience of migration played a formative role in the establishment of women's and gender history. Moreover, I discuss what the invitation of twelve Nigerian students in 1958 had to do with the invisibilisation of democratic deficits in Switzerland and how this can be historically connected to fighting women in Nigeria and Switzerland.
\end{abstract}

Keywords Female suffrage - The intersection of discrimination and privileges - Indirect experience of migration - Cultural memory • The establishment of women's and gender history $\cdot$ Unseen democratic deficits

F. Falk, Gender Innovation and Migration in Switzerland, Palgrave Studies in Migration History, https://doi.org/10.1007/978-3-030-01626-5_6 


\section{Female Suffrage in Switzerland and Its Relation to Migration}

Whereas Switzerland was, as we have seen, a pioneer in making higher education accessible to women, we will now examine Switzerland as an extreme latecomer in another domain. Even if the history of female suffrage in Switzerland is well documented in many respects, its relation to migration has never been systematically analysed. The present chapter will show how some of the most prominent figures in the struggle for female suffrage were related to experiences of migration (and more cases await further analysis). ${ }^{1}$

Historians have long noted the seeming paradox that Switzerland introduced universal male suffrage very early, but female suffrage very late. ${ }^{2}$ Switzerland has a system of semi-direct democracy, a factor that has (often without further reflection) been held responsible for this exceptionally late adoption of female suffrage. It was-so the argument goes-because the majority of men had to vote on female suffrage that it proved so difficult to pass. Even if in those days some groups of men were still excluded from political participation (e.g. Jews and those dependent on financial assistance), it has to be acknowledged that in Switzerland the right to political participation-or not-followed gender lines comparatively early on. ${ }^{3}$ Later, this was also an important

${ }^{1}$ See, for instance, the biographies of Maria Eugster-Breitenmoser, Lotti Ruckstuhl, Annie Reineck, Pauline Chapponnière-Chaix, Auguste de Morsier, Georgine Emma Gerhard, or Dora Schmidt. See SVF, Der Kampf um gleiche Rechte, Basel: Schwabe 2009.

${ }^{2}$ Sibylle Hardmeier, Frühe Frauenstimmrechtsbewegung in der Schweiz (1890-1930). Argumente, Strategien, Netzwerk und Gegenbewegung, Zürich: Chronos Verlag 1997; Sibylle Hardmeier, Die Vereine in der Deutschweiz und die Gründung des schweizerischen Verbandes, in SVF, Der Kampf um gleiche Rechte, Basel: Schwabe 2009, 67-78; Brigitte Studer, Das Frauenstimm- und -wahlrecht in der Schweiz 1848-1971. Ein 'Fall' für die Geschlechtergeschichte, in Braunschweig, 'Als habe es die Frauen nicht gegeben'. Beiträge zur Frauen- und Geschlechtergeschichte, Zürich: Chronos 2014, 179-196; Yvonne Voegeli, Zwischen Hausrat und Rathaus. Auseinandersetzungen um die politische Gleichberechtigung der Framen in der Schweiz 1945-1971, Zürich: Chronos Verlag 1997; Franziska Rogger, 'Gebt den Schweizerinnen ibre Geschichte!' Marthe Gosteli, ihr Archiv und der übersehene Kampf ums Frauenstimmrecht, Zürich: NZZ Libro 2015. See also Beatrix Mesmer, Ausgeklammert - eingeklammert. Frauen und Frauenorganisationen in der Schweiz des 19. Jahrhunderts, Basel: Helbing \& Lichtenhahn 1988.

${ }^{3}$ Caroline Arni, Republikanismus und Männlichkeit in der Schweiz, in SVF, Der Kampf um gleiche Rechte, Basel: Schwabe 2009, 20-31. 
handicap to the introduction of female suffrage, as the reform of the political system became a women-only affair. ${ }^{4}$ At the national level, women gained the right to vote in 1971, while in some cantons female voting rights were withheld even longer, the last canton being Appenzell Innerrhoden, which finally was forced to introduce female suffrage in 1990 by the Swiss Federal Court.

\section{The First Formal Association Promoting Political AND Legal Equality for Women}

The first formal association promoting political and legal equality for women was established in Geneva in 1868 by Marie Goegg-Pouchoulin as part of an international movement for peace. She was also the initiator of the petition that successfully opened the doors for women at the University of Geneva in $1872 .{ }^{5}$ Her ancestors were French Huguenots who had fled to Switzerland after the revocation of the Edict of Nantes. Both her grandfather and her father were watchmakers, an occupation known for its association with socialist and anarchist ideas. When she was already married and the mother of a little boy, she met some refugees of the 1848 Revolution, who had rented rooms in her parents' house. She fell in love with Amand Goegg, one of the leaders of the uprising in Baden (Germany), and demanded a divorce from her husband. As he did not consent, legally they were merely separated. In 1851, Amand Goegg was expelled from Switzerland and went to Paris and later to London. Afterwards, he lived again in Geneva, probably illegally. In 1853, Marie Pouchoulin realised that she was pregnant. Under adventurous circumstances, both travelled to London, taking Marie's now seven-yearold son with them. We do not know how she experienced this stay in London. But it seems very probable that it was there that her interest in

\footnotetext{
${ }^{4}$ Regina Wecker, Staatsbürgerrechte, Mutterschaft und Grundrechte, Schweizerische Zeitschrift für Geschichte 46, 3 (1996), 383-410.

${ }^{5}$ In what follows see Susanna Woodtli, Gleichberechtigung. Der Kampf um die politischen Rechte der Frau in der Schweiz, Frauenfeld: Huber 1983, 24-49. Mesmer, Ausgeklammert - eingeklammert. Frauen und Frauenorganisationen in der Schweiz des 19. Jahrhunderts, Basel: Helbing \& Lichtenhahn 1988, 88-93, 102-110. Ruth Nattermann, Frauen in der europäischen Friedensbewegung. Die Association Internationale des Femmes (18681914) (2015), in: http://www.europa.clio-online.de/site/lang_de/ItemID_744/ mid_11428/40208214/default.aspx (12 January 2016).
} 
feminism grew. In her novel Deux poids et deux mesures, she developed her first emancipatory ideas-tellingly through a female character who is English. Moreover, the name she chose for the organisation she founded in order to fight for equal rights, the Association Internationale des Femmes, testifies to the extent to which had been inspired by the International Workingmen's Association founded 1864 in London. Her idea of establishing clubs providing specialised reading also derived from there.

\section{Migrating Political Strategies}

Marie Goegg-Pouchoulin's diverse experience of migration was far from a unique case. Iris von Roten (1917-1990) became an icon of Swiss feminism by publishing a provocative book at the time of the first national plebiscite on female suffrage in Switzerland in 1959. Two experiences of migration were crucial for her. ${ }^{6}$ First, there was a case of internal migration-and such internal migration is often neglected in historical researchfrom one of the biggest cities in Switzerland to a rural area, which led to an intensive experience of discrimination. Iris von Roten was the first female lawyer in the canton of Valais, and clients did not want to be represented by a woman. In addition, von Roten lived in the USA for a year, where she conceived and drafted her soon-to-become notorious book Framen im Laufgitter.?

Not only her writing benefited from her experience abroad, but also the political strategies that she and her husband employed in campaigning for female suffrage. ${ }^{8}$ In 1957, the women of Unterbäch, a small mountain village in the Swiss canton of Valais, were allowed to participate in a national referendum on the question of whether civil defence service should become mandatory for Swiss women. The chairman of the municipality and the Nationalrat (i.e. federal representative) for the Canton of Valais, Peter von Roten - the husband of Iris von Roten ${ }^{9}$ were the initiators of what, at the time, was perceived as a scandal.

\footnotetext{
${ }^{6}$ In addition, a very important research stay in Oxford ought to be mentioned.

${ }^{7}$ Iris Roten, Frauen im Laufgitter. Offene Worte zur Stellung der Frau, Bern: Hallwag 1958.

${ }^{8}$ Regina Wecker, Travelling Strategies, Travelling Women: Iris von Roten's Swiss Book, in Pender and Burns, Crossing Frontiers: Cultural Exchange and Conflict. Papers in Honour of Malcolm Pender, Amsterdam: Editions Rodopi 2010, 163-184.

${ }^{9}$ Wilfried Meichtry, Verliebte Feinde. Iris und Peter von Roten, Zürich: Ammann 2007.
} 
They argued that the village community was legally authorised to set up its voting register. The women's votes were, however, collected in a separate ballot box and never formally counted. Nevertheless, this procedure generated considerable attention, and even the New York Times sent correspondents to report from this village of 400 inhabitants.

Interestingly, the Unterbäch strategy looked a lot like the approach American women had pursued in their campaign to gain the vote. According to Regina Wecker, Iris von Roten had studied the American women's struggle 'and may have come across that strategy which seemed so exotic in a small place in the Swiss mountains' ${ }^{10}$

\section{The Last Stragglers}

Small spaces are also characteristic for our last examples, in which we analyse the special situation in the two cantons of Appenzell Innerrhoden and Appenzell Ausserrhoden. The predominately Catholic Appenzell Innerrhoden, with approximately 16,000 inhabitants today, and the largely Protestant Ausserrhoden, with currently about 54,000 inhabitants, were the last two Swiss cantons to introduce female suffrage. It was only in 1989 that the male citizens of Appenzell Ausserrhoden narrowly voted for women's suffrage in the traditional Landsgemeinde, an annual open-air assembly of all (until 1990 only male) citizens, where public voting on cantonal matters was - and still is in Appenzell Innerrhoden-conducted by a show of hands.

For this canton, the most iconic figure of women's suffrage movement is considered to be Elisabeth Pletscher (1908-2003). ${ }^{11}$ She had been raised in Appenzell Ausserrhoden and was the great-great-granddaughter of the Landammann (Chairman of the Canton) Jacob ZellwegerZuberbühler (who had even been invited to Napoleon's coronation). ${ }^{12}$ This family was involved in textile and colonial trade activities throughout

\footnotetext{
${ }^{10}$ Wecker, Travelling Strategies, Travelling Women: Iris von Roten's Swiss Book, in Pender and Burns, Crossing Frontiers: Cultural Exchange and Conflict. Papers in Honour of Malcolm Pender, Amsterdam: Editions Rodopi 2010, 163-184, 178.

${ }^{11}$ Elisabeth Pletscher received an honorary doctorate degree from the University of St. Gallen in 1998. Renate Bräuniger, Elisabeth Pletscher (*1908) - kein Mangel an öffentlicher Resonanz, in Bräuniger, FramenLeben Appenzell. Beiträge zur Geschichte der Frauen im Appenzellerland, Herisau: Appenzeller Verlag 1999, 424-441, 431.

${ }^{12}$ Hans Fässler, Reise in Schwarz-Weiss. Schweizer Ortstermine in Sachen Sklaverei, Zürich: Rotpunktverlag 2005, 46.
} 
the world. Pletscher herself grew up in modest circumstances, as her father died when she was five. She was one of the first girls in the local high school and would have liked to study medicine, but for financial reasons this was not possible.

According to her, she questioned the exclusion of women from the Landsgemeinde for the first time as an 18 years old. ${ }^{13}$ At that time, a Polish woman, who was married to one of her cousins, opened her eyes. This woman had come to Switzerland during the First World War, had studied there, and was now following her husband to the USA. At the farewell in the village square in Trogen, she explained to Elisabeth Pletscher that she was happy to be able to leave Switzerland, because it was a provincial backwater. She told Pletscher that in Poland, women had already had the vote for a long time. Pletscher responded placatingly that women's suffrage would eventually be introduced in Switzerland, and that only here it might not be possible because of the cantonal assembly. "That conversation has stayed with me, I remember where we stood. She answered: "But why not?!" "Because it's only for men", was my argument. "And why not for you?" She continued, "you also go to a school with lots of boys and why should you not participate like this later in polls and elections?" It suddenly dawned on me. I thought she was right'.

In addition to this encounter, Pletscher's own migration experience was decisive for her political engagement. She had in fact spent her whole professional life as a chief laboratory technician at the Women's Hospital Zurich. After her retirement, she returned to her birthplace in 1973, and consequently lost the right to vote at the cantonal level, which she had had in Zurich. This experience had a lasting effect on her political engagement. Elisabeth wrote in 1973: 'Personally, I have recently been demoted from a full-citizen in the Canton of Zurich to a $2 / 3$ citizen in the Canton of Appenzell'. ${ }^{14}$

${ }^{13}$ In what follows, see Hanspeter Strebel and Kathrin Barbara Zatti, 'Es gibt Dinge, die brauchen Zeit'. Elisabeth Pletscher, Zeitzengin des 20. Jabrhunderts, Herisau: Appenzeller Verlag 2005, 91 .

14 'Persönlich bin ich von einer Voll-Bürgerin im Kanton Zürich seit kurzem zurückversetzt worden in eine 2/3-Bürgerin im Kanton Appenzell'. Elisabeth Pletscher, Rückblick auf selbsterlebte 'Emanzipation der Frau', Mitteilungen des Kantonsschulverein Trogen, Trogen: Eigenverlag 1973, 42-45, 44. 
In 2004, Julia Nentwich conducted a series of in-depth interviews with individuals who had acted as agents of change in both cantons. A male activist for female suffrage explained to Nentwich that, before going to the Landsgemeinde, Pletscher always very consciously wore a traditional costume, and that she then used to speak in her most pronounced local dialect (whereas on other occasions, her dialect was less marked). ${ }^{15}$ What we see here is a prototypical situation in which the necessary impulses for change came from the outside. At the same time, they needed to be perceived as coming from the inside in order to be seen as legitimate. ${ }^{16}$

We can find a similar situation in the even more conservative Appenzell Innerrhoden. As late as 1990, the (Swiss) men residing in the canton rejected female suffrage at the cantonal-as opposed to the federal-level at the Landsgemeinde. By consequence, a constitutional complaint was brought before the Swiss Federal Court, which eventually declared this treatment of women to be unconstitutional, thus overruling the men's decision. In her interview with Nentwich, a woman active in the Action Committee for Women's Suffrage in Appenzell Innerrhoden stated that the initiator of the first legal action, ${ }^{17}$ Theresa Rohner, had moved from Appenzell Ausserrhoden to Innerrhoden. As a result of her political involvement, Theresa Rohner also received death threats. According to the interviewee, it was possible only for an 'outsider' to get involved in something like this: '[S]he was capable of doing it, that's my personal theory, because she was not from Innerrhoden $[\ldots]^{\prime}$. $^{18}$ Here, we see that great importance can be attributed to an experience of migration that took place on a very small scale.

15 "Bewusst hat sie an der Landsgemeinde die Tracht angezogen, obwohl sie jetzt keine Bauersfrau ist, aber sie hat dann die Tracht angehabt und hat dann ihren Appenzeller Dialekt (gesprochen). Sie ist sehr sprachbegabt, sie konnte auch umstellen, sie konnte mehr oder weniger 'appenzellern'” Julia C. Nentwich, Zwischen Provokation und Anpassung: Handlungsmächtigkeit als diskursive Positionierung (2009), in: http://www.qualitative-research.net/index.php/fqs/article/view/1197 (1 July 2016).

${ }^{16} \mathrm{Ibid}$.

${ }^{17}$ Later, there were other legal actions.

${ }^{18}$ Julia C. Nentwich, Mustafa F. Ozbilgin, and Ahu Tatli, Change Agency as Performance and Embeddedness: Exploring the Possibilities and Limits of Butler and Bourdieu, Culture and Organization 21, 3 (2015), 235-250, 245. 


\section{An Indirect Experience of Migration}

A good ten years earlier, in 1978, the pioneering attempt to establish a political women's group campaigning for political rights in Appenzell Innerrhoden had been initiated by Ottilia Paky-Sutter. ${ }^{19}$ Some seventy women met at the founding event for a female suffrage association. But Paky's goal to have native women, preferably with a rural background, appear in newspaper advertisements asking for female suffrage, in order to refute the assertion that only newcomers wished political rights, was not achieved.

Ottilia Sutter belonged to one of the most well-known local families. They owned an inn where the 'intelligentsia' of Appenzell met. During the Second World War, she and her sister performed at the national exhibition Landesausstellung aimed at strengthening Swiss national identity. From then on, the two singing sisters were seen as paragons of local traditions, and therefore, it comes as no surprise that, in 1945, when General Guisan ${ }^{20}$ visited Appenzell, they were chosen to pose for a photograph with him. Just a few years later, the situation changed completely. In 1947, Ottilia Paky-Sutter lost her Swiss citizenship because she married an Austrian. By contrast, if a Swiss man married a 'foreigner', the wife would at that time automatically become a Swiss citizen. Brigitte Studer has brilliantly explained these procedures in her essay on practices and controversies surrounding the special legal treatment of women according to their marital status. In contrast to male citizens, the civic membership of Swiss women was in fact a contingent one. ${ }^{21}$

In 2014, I interviewed the daughter of Ottilia Paky-Sutter. According to her, the decisive factor for her mother's engagement on behalf of female suffrage was the very fact that she had lost her Appenzell, as well as her Swiss, citizenship due to her marriage. ${ }^{22}$ Paky regarded this

${ }^{19}$ In what follows, see the highly interesting article by Vreni Mock, Ottilia Paky-Sutter (*1918) - eine Österreicherin fordert das Stimmrecht, in Bräuniger, FrauenLeben Appenzell. Beiträge zur Geschichte der Frauen im Appenzellerland, Herisau: Appenzeller Verlag 1999, $408-415$.

${ }^{20}$ During the Second World War, Henri Guisan held the office of the General of the Swiss Armed Forces.

${ }^{21}$ Brigitte Studer, Citizenship as Contingent National Belonging: Married Women and Foreigners in Twentieth-Century Switzerland, Gender \& History 13, 3 (2001), 622-654.

${ }^{22}$ Statement made by her daughter in a personal conversation, 23 December 2014: "Was eigentlich den Ausschlag gab, dass sie für das Frauenstimmrecht kämpfte, war, dass sie das Appenzeller und Schweizer Bürgerrecht verloren hatte mit ihrer Hochzeit”. 
change as a social demotion. The whole family had to become naturalised again, a humiliating and costly procedure for them. It was this kind of indirect migration experience that provoked her political engagement for women's political rights. Again, certain privileges intersected here with specific forms of discriminations and produced a situation where new political reconfigurations became possible-in this case, the political engagement for female suffrage.

This last example of a woman who lost her citizenship because she married a 'non-national' shows that it can be heuristically productive, when studying migration, to include those experiences that do not involve any actual physical movement. I am convinced that such an approach can be highly rewarding, as such processes are most often neglected. By redressing this bias, we are able to rethink the implications of migration more broadly. For instance, in Switzerland today, fewer than $50 \%$ of marriages are concluded between Swiss citizens, ${ }^{23}$ and this has a decisive impact on society as a whole. Paying particular attention to such indirect migration experiences thus allows us to see how migration policies affect far more people than those who are usually considered as 'migrants'. In this context, however, it is important to stress that this does not mean losing sight of specific privileges or forms of discrimination, quite the opposite.

\section{Not Downplaying the Effects of Racism}

On my understanding, using a broad concept of migration in fact means the opposite of being blind to differences. We should not downplay the effects of racism or of different legal situations. Therefore, it is always necessary to acknowledge distinctions between various kinds of relocations-for example, with regard to the legal status or racialising categories.

Tilo Frey, for instance, was one of ten women elected as a Swiss National Councillor in the first national election after the introduction of female suffrage in $1971 .{ }^{24}$ She had been born in Maroua as the daughter

${ }^{23}$ http://www.bfs.admin.ch/bfs/portal/de/index/themen/01/06/blank/key/05/01. html (15 August 2016).

${ }^{24}$ On the involvement of women in political parties after 1971, see Fabienne Amlinger, Im Vorzimmer zur Macht? Die Frauenorganisationen der SPS, FDP und CVP (1971 bis 1995), Zürich: Chronos 2017. 
of a mother living in Cameroon and a Swiss father. After being adopted, she came to Switzerland at the age of five. Tilo Frey was the first and last Black woman to be elected to the Swiss national parliament. In an interview in 2007, she recalled that before and after her election she was repeatedly described as a dirty $\mathrm{N}^{*}$, as Jovita dos Santos Pinto has pointed out. ${ }^{25}$ During Tilo Frey's term of office, which lasted until 1975, she advocated for equal pay, the right to abortion and development cooperation. In addition, she worked as a teacher and later as a school director. In 2018, it was decided to rename Espace Louis Agassiz-a street on which the University of Neuchâtel's Faculty of Arts and Human Sciences is located-Espace Tilo Frey, to mark the ten-year anniversary since her death.

\section{Women's Right to Vote in Cultural Memory}

It was only in 2017 that the first feature film on the introduction of women's voting rights in Switzerland was made. The screenwriter and director, Petra Biondina Volpe, is both Italian and Swiss. In the same year, Mohamed Wa Baile published a children's book on this topic (the first to my knowledge). ${ }^{26}$ Both authors have experienced migration. The main initiator behind the book on the lives of women in Appenzell was Renate Bräuniger. She was born in Germany and came to Switzerland to study sociology, where she married and remained. As editor and coauthor, Bräuniger published 'FrauenLeben Appenzell', a book of 735 pages. Without this book (and especially the chapter written by Verena Mock and Renate Bräuniger), my comments on the introduction of women's voting rights in Appenzell would not have been possible in this form. According to Verena Mock, her article about Paky-Sutter would not have been written without this book project: 'I wouldn't know who else could have given me this assignment. I was not a historian either, but studied philosophy and German. As I come from a completely non-academic farming family, I had no network'. ${ }^{27}$ Mock explained

\footnotetext{
${ }^{25}$ Jovita Dos Santos Pinto, Spuren. Eine Geschichte Schwarzer Frauen in der Schweiz, in Berlowitz, Joris, and Meierhofer-Mangeli, Terra incognita? Der Treffpunkt Schwarzer Framen in Zürich, Zürich: Limmat Verlag 2013, 143-185, 160.

${ }^{26}$ Mohamed Wa Baile and Manuela Solinger, Wie die Frauen zu ibren Rechten kamen, Küsnacht: C. F. Portmann Verlag 2017.

${ }^{27}$ Statement made in a personal conversation, 29 April 2018 and via e-mail, 2 May 2018.
} 
that her contribution went back to her 'Swiss Youth Research' work in 1988. ${ }^{28}$ Although it was graded 'outstanding', the local publisher of the newspaper 'Appenzeller Volksfreund' did not want to include the work in its publication series 'Innerrhoder Schriften'. On the other hand, they had published the work of a classmate who had participated in the competition a year earlier, although it was much more subject specific and less readable (on the topic of the grammar of verbs in the Appenzell dialect). This offended her, but she never thought of making her own publication or looking for another publisher. No one would have asked her to make anything of it, until Renate Bräuniger came.

Julia Nentwich, whose interviews with women's voting rights activists were also extremely important for this chapter, obtained her doctorate at the University of Tübingen. She is now Professor of Psychology at the School of Humanities and Social Sciences of the University of St. Gallen. Regina Wecker, too, whom I quote several times in this study and who was the first female assistant at the History Department at the University of Basel and the first person in Switzerland to hold a chair for the history of women and gender (since 1997), ${ }^{29}$ also came to Switzerland from Germany. ${ }^{30}$ And the fact that the University of Zurich recently honoured Nadeschda Suslowa as a pioneer in the fight for women's access to universities is due to a suggestion by Professor Nada Boškovska. ${ }^{31}$ Boškovska was born in Macedonia, but has lived in Switzerland since she was 9 years old. ${ }^{32}$

These examples show that it could be a stimulating undertaking to systematically investigate how, in Switzerland, women with experience of migration played a formative role in the establishment of women's and gender history (and more general gender studies).

${ }^{28}$ Verena Mock, Das Frauenstimmrecht in Appenzell Innerrhoden. Geschichte einer verzögerten politischen Emanzipation, Unpublished 1988.

${ }^{29}$ Ulla Bock, Pionierarbeit. Die ersten Professorinnen für Frauen- und Geschlechterforschung an deutschsprachigen Hochschulen 1984-2014, Frankfurt am Main: Campus 2015, 60 .

${ }^{30}$ Francesca Falk and Peppina Beeli, Regina Wecker im Gespräch, Bulletin der Schweizerischen Gesellschaft für Geschichte 94 (2014), 20-23.

${ }^{31}$ https://www.hist.uzh.ch/de/ueberuns/forschungsmedien/20170410_boskovskal. html (12 December 2017).

${ }^{32}$ https://www.srf.ch/sendungen/musik-fuer-einen-gast/nada-boskovska-professorin-fuer-osteuropaeische-geschichte (12 June 2017). 


\section{Unseen Democratic Deficits in the Supposed Heartland of Democracy}

Such an interrelation between migration and sociopolitical innovation can be observed not only in the case of female suffrage. Some years ago, a debate on how decisively the labour movement in Switzerland was influenced by people with experience of migration was conducted. ${ }^{33}$ We can learn from this discussion to keep in mind the ambivalent situation that, on the one hand, 'foreigners' were often seen as strike-breakers and therefore an obstacle to the labour movement, and that, on the other hand, social movements were frequently labelled as coming from abroad, a strategy used in order to delegitimise them. In fact, even though different groups of 'migrants' made important contributions to the Swiss labour movement, it would be wrong to see them as being controlled from abroad and not only because these persons often became politicised in Switzerland itself. What is very interesting in such constellations are the relationships built up between the local population and the newcomers, as well as their ability to create novel alliances and to develop new ideas. There are still significant research gaps in this regard, even if there exists, for instance, some research analysing the impact of political refugees on the democratisation of Switzerland. ${ }^{34}$

However, such a perspective has so far rarely been applied systematically. Rather, the development of democracy is seen as a purely internal matter in Switzerland. In addition, the dominant picture of history depicts Switzerland as a heartland of democracy. Yet, if female suffrage is on

\footnotetext{
${ }^{33}$ Marc Vuilleumier, Quelques jalons pour une historiographie du mouvement ouvrier en Suisse, Revue européenne des sciences sociales XI, 29 (1973), 5-35. Charles Heimberg, La question de l'immigration, in Vallotton and Studer, Histoire sociale et mouvement ouvrier, 1848-1998. Sozialgeschichte und Arbeiterbewegung, 1848-1998, Lausanne: Editions d'en bas 1997, 155-161. Mattia Pelli, 'On n'avait peur de rien.' Immigrés et grève à la Monteforno de Bodio (1970-1972), Cahiers d'histoire du mouvement ouvrier 28, 93-114. Not only historians, but also social scientists studied such questions, see, for example, Mark James Miller, Foreign Workers in Western Europe. An Emerging Political Force, New York: Praeger 1981.

${ }^{34}$ See, for example, Werner G. Zimmermann, Asyl in der Schweiz. Aspekte und Dimensionen eines Dauerthemas, in Bankowski, Brang, Goehrke, and Zimmermann, Asyl und Aufenthalt. Die Schweiz als Zuflucht und Wirkungsstätte von Slaven im 19. und 20. Jahrhundert, Basel and Frankurt am Main: Helbling Lichtenhand 1994, 13-18. Ralf Prescher, Der Beitrag deutscher Immigranten zur Demokratieentwicklung in der Schweiz, in Roca, Wege zur direkten Demokratie in den schweizerischen Kantonen. Schriften zur Demokratieforschung, Zürich: Schulthess 2011, 175-201.
} 
the radar, another picture appears. But in the light of the above-mentioned view of history, such democratic deficits simply become invisible.

\section{'A New Swiss Export Article: Instruction in Democracy'}

This can be shown, for instance, in a report published in a Swiss magazine in 1958. ${ }^{35}$ Under the title 'A new Swiss export article: teaching in democracy', it is reported that - in the context of the imminent independencean aid organisation (the later NGO Helvetas) had invited twelve Nigerian students to Switzerland to teach them about democracy. ${ }^{36}$ The article defined Switzerland as a 'School of Democracy'. Its reporting focused, nota bene, mainly on a visit to a centre for basic military training and the Zurich city police-that is obviously where 'democracy' can be learned.

The fact that, in 1958, political participation was still denied to Swiss women at the national level was not mentioned in the article. Riehen was in fact the first municipality to introduce women's voting rights in 1958, and the first Swiss canton introduced women's suffrage in 1959. On the national level, in 1959 women's right to vote was rejected by a two-thirds majority. The fact that women in the south of Nigeria were given political rights earlier (in particular the year 1958 is seen as the official date of female enfranchisement in Southern Nigeria) is not mentioned in the article.

This, in turn, is hardly surprising, because if we were to look at the lack of women's voting rights, then Switzerland could no longer be understood to be the model of democracy. And the idea that perhaps the invited Nigerians could teach 'democracy' to Switzerland was obviously unthinkable. ${ }^{37}$ The following statement from a discussion in the Swiss parliament about the introduction of female suffrage also reflects such a position.

\footnotetext{
${ }^{35}$ G. H., Ein neuer Schweizer Exportartikel: Unterricht in Demokratie, Die Woche. Neme Schweizerische Illustrierte Zeitung, Die Woche. Neue Schweizerische Illustrierte Zeitung 4. 10 August 1958 (1958), 4-5. I would cordially like to thank Elisabeth Joris for this indication.

${ }^{36}$ See also Dos Santos Pinto, Spuren. Eine Geschichte Schwarzer Frauen in der Schweiz, in Berlowitz, Joris, and Meierhofer-Mangeli, Terra incognita? Der Treffpunkt Schwarzer Frauen in Zürich, Zürich: Limmat Verlag 2013, 143-185, 156.

${ }^{37}$ With regard to the current media stereotyping of Nigerians in Switzerland and the long-term impact of colonialism on today's handling of migration, see Francesca Falk, Eine postkoloniale Perspektive auf die illegalisierte Immigration in der Schweiz. Über Ausschaffungen, den 'Austausch mit Afrika', Alltagsrassismus und die Angst vor der umgekehrten Kolonisierung, in Purtschert, Lüthi, and Falk, Postkoloniale Schweiz. Formen und Folgen eines Kolonialismus obne Kolonien, Bielefeld: Transcript 2012, 201-224. A
} 
In 1958, the National Council debated the vote to be held one year later. The Liberal member of parliament Jacques Chamorel supported holding a national vote for the following reasons: 'Where women's suffrage will have won an impressive majority, it must be introduced in the municipality or the canton; and in regions where it meets with strong opposition, at least proof will be given that there, in any case, it does not respond to a desire or a necessity'. ${ }^{38}$ According to Yvonne Voegeli, he was probably one of those who agreed to the bill in the Council in order to reject it in the popular vote for men. ${ }^{39}$ In this context, two others statements made by Chamorel in his speech are particularly noteworthy: 'It is not acceptable that the day after she married a Confederate, a foreigner who has never lived with us could immediately exercise the right to vote'. Chamorel therefore supported a vote about the introduction of female suffrage, but not female suffrage per se. In fact, it seemed particularly dangerous to him that those 'foreign' women who became Swiss by marriage should be able to vote immediately. Here, migration is thus used as an argument against women's voting rights. ${ }^{40}$ Chamorel was full of praise for Switzerland's political system. He found that the existence of women's voting rights per se did not mean much: 'A république nègre can institute female suffrage, but it will nonetheless remain a république nègre, while Switzerland has multiplied the signs and evidence of its political maturity, even though women do not vote there'. From such a perspective, it is simply impossible for an African country to be more democratic than Switzerland, because whether it has women's suffrage or not-it remains a 'république nègre'. Switzerland, on the other hand, cannot be undemocratic, no matter what the specific conditions are.

slightly modified re-publication of the article can be found online at Francesca Falk, Eine postkoloniale Perspektive auf die illegalisierte Immigration in der Schweiz. Über Ausschaffungen, den "Austausch mit Afrika", Alltagsrassismus und die Angst vor der umgekehrten Kolonisierung (2012), in: http://iae-journal.zhdk.ch/files/2012/12/ AER6_Falk2.pdf (22 January 2013).

${ }^{38}$ Vormittagssitzung vom 20. März 1958. Séance du 20 mars 1958, matin. 7338. Frauenstimmrecht. Einführung Suffrage feminin. Introduction (1958), in: https://www. amtsdruckschriften.bar.admin.ch/viewOrigDoc/20036530.pdf? $\mathrm{ID}=20036530$ (13 June 2018). My Translation.

${ }^{39}$ Voegeli, Zwischen Hausrat und Rathaus. Auseinandersetzungen um die politische Gleichberechtigung der Frauen in der Schweiz 1945-1971, Zürich: Chronos Verlag 1997, 255.

${ }^{40}$ This was also the case with regard to the argument that only women who moved to Switzerland wanted voting rights for women. 


\section{9: Fighting Women in Nigeria and Switzerland}

In this respect, two incidents in Swiss and Nigerian history are highly interesting. In 1929, a petition was launched in Switzerland by the Swiss women's voting rights association. ${ }^{41}$ In February, a nationwide appeal was published in the press, and in March, the collection of signatures began, which lasted 12 weeks. In the Bernese Oberland, the collection had to be stopped after the collectors had been insulted countless times. Nevertheless, within a short period of time, almost a quarter of a million signatures were gathered-a number never before reached in Switzerland.

In the same year, the Women's War took place in Nigeria. The rebellion, in which tens of thousands Eastern Nigerian women were involved, lasted about a month and extended over an area of six thousand square miles. British officials attributed the Women's War to the rumours that women were to be subjected to taxation. These rumours were used to mobilise women to oppose British rule. ${ }^{42}$ An important element in the background to these protests was, however, also the fact that the colonial government had changed the position of women in society. Even if the position of women was not equal to that of men, Igbo women traditionally had important rights in the public domain and participated in policy-making. ${ }^{43}$ When the British tried to create political institutions which monopolised power, they failed to acknowledge the political roles of women. Socialised in Victorian England, the colonisers discounted political institutions for women while they took into account the political institutions dominated by men. The women's traditional base of political power lay in assemblies of all of the adult women residing in a village. Here, they would discuss their particular interests as traders, farmers, wives, and mothers. These were often opposed to those of the men, and only collectively could they hold their own. If the women's requests were ignored, they would handle the matter by launching a boycott or a

\footnotetext{
${ }^{41}$ Hardmeier, Frühe Frauenstimmrechtsbewegung in der Schweiz (1890-1930). Argumente, Strategien, Netzwerk und Gegenbewegung, Zürich: Chronos Verlag 1997, 299-305.

${ }^{42}$ Toyin Falola and Adam Paddock, The Women's War of 1929. A History of Anti-Colonial Resistance in Eastern Nigeria, Durham, NC: Carolina Academic Press 2011, 97.

${ }^{43}$ In what follows, see Judith Van Allen, 'Sitting on a Man': Colonialism and the Lost Political Institutions of Igbo Women, Canadian Journal of African Studies/Revue Canadienne des Études Africaines 6, 2 (1972), 165-181.
} 
strike or by 'sitting on a man'. In this case, women would gather at the residence of the offender. By invading his space, they forced him to pay attention. They danced and sang songs which specified their grievances against him and often called his manhood into question. Sometimes, they demolished his hut or plastered it with mud. This kind of protest was considered as legitimate by the local population. The Women's War practised 'sitting on a man' on a larger scale. The women 'sat on' numerous local chiefs to demand their resignation, damaged native courthouses, looted European trading firms, and blocked roads. The colonial troops fired on the protesters; more than fifty women were killed.

In Judith Van Allen view, despite some political changes initiated by the Women's War-the colonial authorities were forced, for instance, to replace some local rulers-women were thereafter excluded from most political processes in the colonial system. ${ }^{44}$ She therefore regarded the Women's War as, ultimately, a failure. According to Van Allen, Western notions about gender roles imposed by the colonial regime blocked future large-scale political participation by women. As the political participation of women depended on the diffuseness of the political power, institutions on the Western model created a system in which there was 'no place for group solidarity, no place for what thereby became 'extra-legal' or simply illegal forms of group coercion, and thus very little place for women' ${ }^{45}$ In this way, the colonial state eliminated the women's ability to protect their own interests and made them dependent upon men for protection against other men.

Such a view has been contested by arguing that women continued to participate in Nigeria's political life. Researchers pointed out that the Women's War established a model for future protest. In addition, it changed the identity of its participants: women across southeastern Nigeria would transcend both the limits of their particular village and colonial administrative divisions by involving themselves in a mass

\footnotetext{
${ }^{44}$ Falola and Paddock, The Women's War of 1929. A History of Anti-Colonial Resistance in Eastern Nigeria, Durham, NC: Carolina Academic Press 2011, 99.

${ }^{45}$ Van Allen, 'Sitting on a Man': Colonialism and the Lost Political Institutions of Igbo Women, Canadian Journal of African Studies/Revue Canadienne des Études Africaines 6, 2 (1972), 165-181, 178.
} 
movement. As a further result, these women were more closely studied that in any other area of Africa. From such a perspective, the Women's War is a historic example of both a feminist and an anti-colonial protest.

In Switzerland in 1929, the petition for female suffrage was delivered-after a small demonstration-to the Bundeshaus, the seat of the Swiss government and parliament. The petition, however, had no consequences. When it had been launched, the women's voting rights association deliberately refrained from initiating a popular initiative. The collection of signatures was intended to exert moral, but not direct political pressure. And so, shortly afterwards, a proposal was dropped to submit the petition-which had been signed by 170,000 women and 79,000 men - as a popular initiative. The collection of signatures was therefore used as an instrument of articulation, but not as a direct means of exerting pressure, because the Swiss women's voting rights association did not want to risk defeat in a vote. ${ }^{46}$ As already mentioned, it was not until 1959 that the first national vote on women's voting rights took place in Switzerland (rejected by a two-thirds majority) and only in 1990 did the last Swiss canton introduce female suffrage.

${ }^{46}$ Sibylle Hardmeier, Neue Mobilisierungsstrategien und die Petition von 1929, in SVF, Der Kampf um gleiche Rechte, Basel: Schwabe Verlag 2009, 123-133, 131. 
Open Access This chapter is licensed under the terms of the Creative Commons Attribution-NonCommercial-NoDerivatives 4.0 International License (http://creativecommons.org/licenses/by-nc-nd/4.0/), which permits any noncommercial use, sharing, distribution and reproduction in any medium or format, as long as you give appropriate credit to the original author(s) and the source, provide a link to the Creative Commons license and indicate if you modified the licensed material. You do not have permission under this license to share adapted material derived from this chapter or parts of it.

The images or other third party material in this chapter are included in the chapter's Creative Commons license, unless indicated otherwise in a credit line to the material. If material is not included in the chapter's Creative Commons license and your intended use is not permitted by statutory regulation or exceeds the permitted use, you will need to obtain permission directly from the copyright holder.

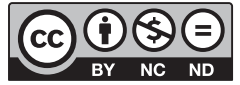

